\title{
Secular trend of the equilibrium-line altitude on the western side of the southern Andes, derived from radiosonde and surface observations
}

\author{
Jorge F. CARRASCO, ${ }^{1,2}$ Roberto OSORIO, ${ }^{1}$ Gino CASASSA ${ }^{2}$ \\ ${ }^{1}$ Dirección Meteorológica de Chile, Casilla 717, Santiago, Chile \\ E-mail: jcarras@meteochile.cl \\ ${ }^{2}$ Centro de Estudios Científicos, Av. Arturo Prat 514, Casilla 1469, Valdivia, Chile
}

\begin{abstract}
The altitude of the $0^{\circ} \mathrm{C}$ isotherm obtained from radiosonde data of the aerological Chilean stations Antofagasta, Quintero/Santo Domingo, Puerto Montt and Punta Arenas are analyzed, along with surface temperature and precipitation records from nearby stations. The strong effect of the 1976/ 77 climate shift due to a change in the Pacific Decadal Oscillation is evident in the temperature and precipitation data. The data are used as input for an empirical model which reconstructs annually the equilibrium-line altitude (ELA) for the last 49 years on the western side of the southern Andes. The model takes air temperature, precipitation and altitude as the main parameters, and was first developed by Fox (1993) and applied by Condom and others (2007). From the radiosonde data, a significant positive trend of the $0^{\circ} \mathrm{C}$ isotherm has occurred in the northern, central and southern regions, indicating an ELA rise due to regional warming. General glacier retreat, ice thinning and negative mass balance observed during the past few decades in virtually all the Chilean Andes concur with the observed ELA reconstruction. In the Punta Arenas radiosonde record there is slight evidence for precipitation increase but no evidence for significant warming in the past few decades. This results in a slight lowering of the ELA according to the model reconstruction, which does not agree with the strong and increased glacier retreat observed in recent decades in Patagonia.
\end{abstract}

\section{INTRODUCTION}

Recent conclusions of Working Group I of the Intergovernmental Panel on Climate Change (IPCC; Solomon and others, 2007) indicate that instrumental meteorological records show an overall warming around the globe, as well as changes in precipitation regimes. There is very high confidence now that a major part of this warming is due to anthropogenic emission of greenhouse gases (IPCC; Solomon and others, 2007). The warming has triggered physical and biological changes in the Earth's system, such as global sea-level rise, decrease of the Arctic sea-ice extent and thickness, generalized retreat and areal reduction of glaciers in the Arctic and in mountain regions around the world, areal decrease of winter snow cover in the Northern Hemisphere (Lemke and others, 2007), earlier spring runoff due to enhanced snowmelt, enhanced glacial runoff, warming of lakes and upward and northward migration of biological species in the Northern Hemisphere (Rosenzweig and others, 2007).

A general trend of tropospheric warming and precipitation changes is also observed in Chile (e.g. Aceituno and others, 1993; Rosenblüth and others, 1995, 1997; Carrasco and others, 2002, 2005; Quintana, 2004). A strong retreat and areal reduction of mountain glaciers has been documented in the Chilean Andes (e.g. Casassa, 1995; Rivera and others, 2000, 2007; Bown and Rivera, 2007; Casassa and others, 2008). A positive trend in the elevation of the equilibrium-line altitude (ELA), during the last quarter of the 20th century in central Chile, has been reported by Carrasco and others (2005) and Osorio (2006).

Figure 1 summarizes available mean annual variations of frontal positions of several glaciers along the Chilean Andes (see Fig. 2 for geographical location). Most of the glaciers show a retreat of the frontal tongue, with maximum recession and thinning in Hielo Patagónico Norte and Sur (northern and southern Patagonian Icefields) (Rignot and others, 2003). The overall warming and changes in precipitation along the Andes are believed to be responsible for the observed glacier variations.

Here we use meteorological information available from Chilean radiosonde stations in combination with data from surface stations as input within a simple empirical model to derive and analyze the behaviour of the ELA as a proxy for assessing glacier variations. This study extends the analysis carried out in the Andes of central Chile by Carrasco and others (2005). In this work the annual average of the $0^{\circ} \mathrm{C}$ isotherm altitude derived from the vertical air-temperature profiles is used, along with precipitation records from surface stations, to determine the annual ELA and its variability at the four radiosonde sites available in Chile. These sites represent the northern $\left(\sim 18-30^{\circ} \mathrm{S}\right)$, central $\left(\sim 30-38^{\circ} \mathrm{S}\right)$, southern $\left(\sim 38-46^{\circ} \mathrm{S}\right)$ and austral $\left(\sim 46-55^{\circ} \mathrm{S}\right)$ regions of Chile, referred to as regions $1-4$, respectively, in this work. An overview and an update of the near-surface air-temperature and precipitation pattern in Chile over the past 45-50 years are also given.

\section{DATA ANALYSIS}

\section{Radiosonde data}

Daily upper-level meteorological observations started in Chile during the International Geophysical Year (IGY, 1957/ 58), when radiosonde stations were deployed at Antofagasta $\left(23^{\circ} 26^{\prime} \mathrm{S}, 70^{\circ} 26^{\prime} \mathrm{W}\right.$; $135 \mathrm{~m}$ a.s.I.), Quintero $\left(32^{\circ} 47^{\prime} \mathrm{S}\right.$, $71^{\circ} 33^{\prime} \mathrm{W} ; 8 \mathrm{~m}$ a.s.I. $)$ and Puerto Montt $\left(41^{\circ} 26^{\prime} \mathrm{S}, 73^{\circ} 07^{\prime} \mathrm{W}\right.$; 81 ma.s.I.). In 1972 a fourth station was started at Punta 


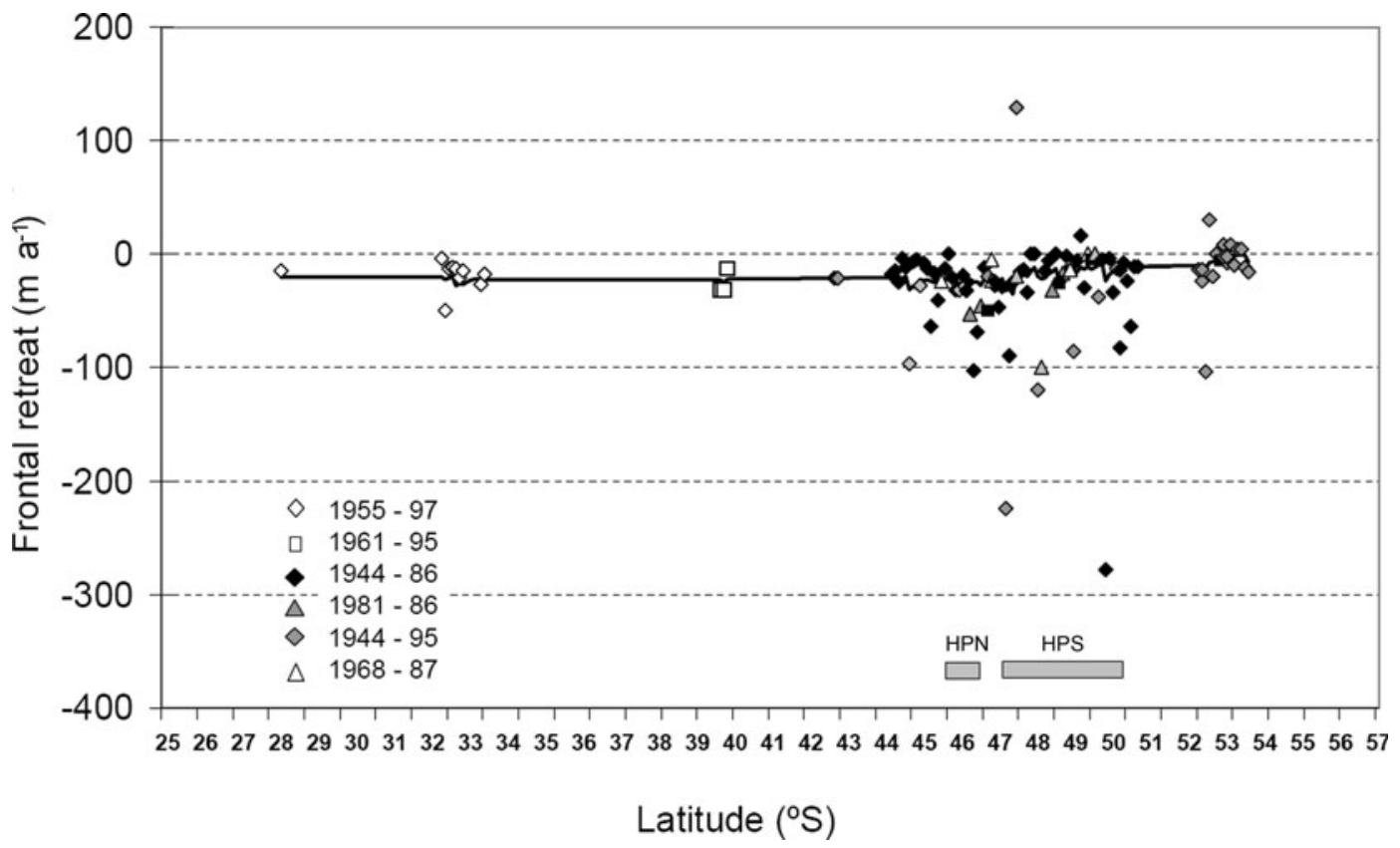

Fig. 1. Mean annual frontal variation of glaciers along the western side of the Andes. Data are derived from aerial photography and satellite imagery acquired at different epochs (Rivera and others, 2002). The grey horizontal bars indicate the latitudinal position of Hielo Patagónico Norte (HPN) and Hielo Patagónico Sur (HPS). The black curve is an exponential regression of all data points which shows an overall retreat of glaciers along the Chilean Andes.

Arenas $\left(53^{\circ} 00^{\prime} \mathrm{S}, 70^{\circ} 07^{\prime} \mathrm{W} ; 37 \mathrm{~m}\right.$ a.s.I. $)$. In 1999 , the aerological station in Quintero was moved $\sim 100 \mathrm{~km}$ south, to its new location at Santo Domingo $\left(33^{\circ} 38^{\prime} \mathrm{S}, 71^{\circ} 18^{\prime} \mathrm{W}\right.$; $77 \mathrm{~m}$ a.s.l.). Almost continuous time series of tropospheric and stratospheric temperatures are available since 1958 for the first three stations and since 1973 for Punta Arenas.

Upper-air temperatures above the boundary layer at $850 \mathrm{hPa}$ for the four radiosonde stations show a warming over the 1958-2006 period as summarized in Table 1. A slight cooling is observed only in summer at Punta Arenas, although it is not statistically significant. A climate shift in $1976 / 77$ can be observed at $850 \mathrm{hPa}$ as well as at 700 and $500 \mathrm{hPa}$ (Boiser and Aceituno, 2006), revealing the horizontal and vertical dimension of the changes associated with the Pacific Decadal Oscillation (PDO) in the southeastern region of the Pacific Ocean along western South America.

\section{Surface temperature}

Assuming a linear trend in the annual mean air temperature for 1901-2005, the IPCC Fourth Assessment Report (IPCC; Solomon and others, 2007) indicates that an overall warming ranging from 0.2 to $1.1^{\circ} \mathrm{C}$ has occurred in Chile north of $38^{\circ} \mathrm{S}$, while a cooling of $0.2-0.5^{\circ} \mathrm{C}$ took place in the region between 38 and $43^{\circ} \mathrm{S}$. In fact, an overall cooling of $0.1-0.3^{\circ} \mathrm{C}(10 \mathrm{a})^{-1}$ has occurred along the western coast of central and southern South America (5-30 ${ }^{\circ} \mathrm{S}$ and $35-55^{\circ} \mathrm{S}$, respectively) during the period 1979-2005 (see fig. 3.9 of Trenberth and others, 2007).

Figure 3 shows the secular trend of the near-surface minimum air temperature (in terms of its annual standardized anomalies) for 1961-2006 at several weather stations in Chile for summer (December-February) and winter (JuneAugust). Minimum temperatures are selected because they better capture the long-term changes (King, 1994). The interannual variability was filtered out using doubleexponential smoothing, as described by Rosenblüth and others (1997) and Carrasco and others (2005). As a result, the secular trends were obtained.

The secular trends for the period 1961-2006 show an overall warming north of $40^{\circ} \mathrm{S}$ that ranges between 0.06 and $0.35^{\circ} \mathrm{C}(10 \mathrm{a})^{-1}\left(0.12\right.$ and $\left.0.38^{\circ} \mathrm{C}(10 \mathrm{a})^{-1}\right)$ in summer (winter) and a slight warming south of $47^{\circ} \mathrm{S}$. A cooling that fluctuates from 0.04 to $0.1^{\circ} \mathrm{C}(10 \mathrm{a})^{-1}$ occurred between 40 and $47^{\circ} \mathrm{S}$ (see Table 2 for details). Most of these tendencies can be attributed to the 1976/77 climate shift (Giese and others, 2002). In fact, individual station analysis (Table 2 ) revealed a

Table 1. Secular trend of the air temperature at $850 \mathrm{hPa}\left(\right.$ in $\left.{ }^{\circ} \mathrm{C}(10 \mathrm{a})^{-1}\right)$ for periods $1958-2006 / 1978-2006$ for all stations, except Punta Arenas which only covers the 1975-2006 period

\begin{tabular}{|c|c|c|c|c|c|}
\hline Location & Summer & Autumn & Winter & Spring & Annual \\
\hline Antofagasta & $0.29 * \mid 0.17$ & $0.09 \mid 0.12$ & $0.31 * \mid 0.18$ & $0.26^{*} \mid 0.23$ & $0.22 * \mid 0.17$ \\
\hline Quintero/Santo Domingo & $0.08 \mid 0.04$ & $-0.04 \mid-0.08$ & $0.11 * \mid-0.23$ & $0.04 \mid-0.06$ & $0.15^{*} \mid 0.10$ \\
\hline Puerto Montt & \begin{tabular}{l|l}
$0.14 *$ & 0.08
\end{tabular} & $0.12 \mid-0.06$ & \begin{tabular}{l|l}
$0.13 *$ & 0.02
\end{tabular} & $0.04 \mid-0.01$ & $0.12 \mid-0.02$ \\
\hline Punta Arenas & -0.01 & -0.04 & $0.20 *$ & -0.00 & 0.04 \\
\hline
\end{tabular}

*Significant at $95 \%$. 


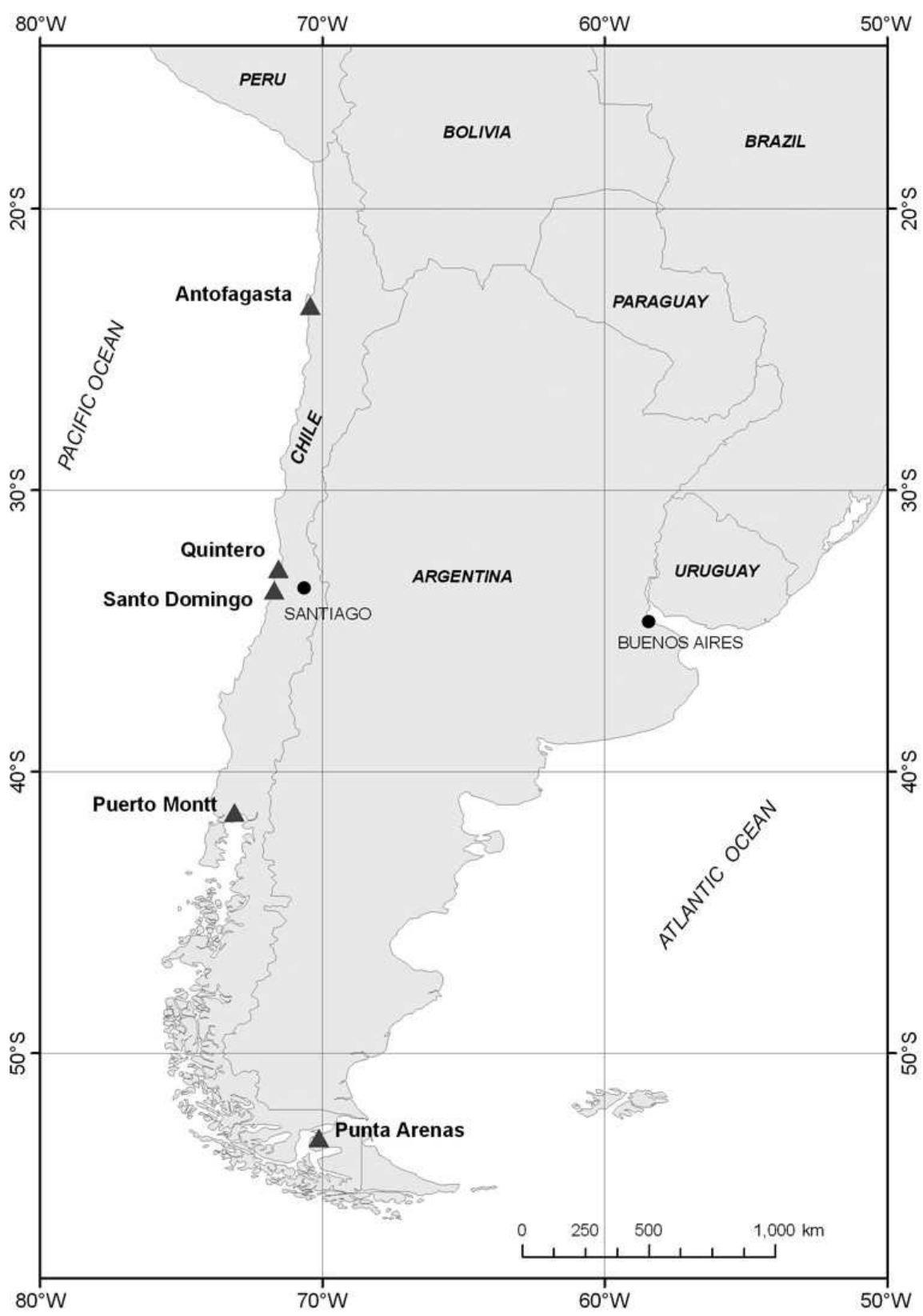

Fig. 2. Location of Chilean radiosonde stations (filled triangles).

slight negative trend (cooling) during the 1977-2006 period for most stations (although not statistically significant), which concurs in part with the Fourth IPCC Report (Trenberth and others, 2007). This behaviour is associated with the PDO, which shows a phase change in 1976/77 (Giese and others, 2002).

\section{Precipitation}

Precipitation in central and southern Chile is mainly of frontal origin with systems that develop in the Pacific Ocean and travel eastward. The north-south seasonal movement of the westerlies results in an annual precipitation cycle with maximum (minimum) amount falling in winter (summer) months (Fig. 4). Thus, $>90 \%$ of the snowfall in the central Andes (between 30 and $38^{\circ} \mathrm{S}$ ) occurs during April to September (Falvey and Garreaud, 2007), while in the southern and austral Andes (including the Patagonian icefields) it snows year round with an annual cycle showing a slight maximum during the winter months. In the northern altiplano (north of $24^{\circ} \mathrm{S}$ ), the precipitation (including snow) takes place during the summertime (from late November to April) being associated with the South American monsoon that brings moist air from the Amazon area towards the eastern side of the Andes (Falvey and Garreaud, 2005).

Figure 5 shows the variation of annual precipitation for all available stations (most of them deployed in the coastal and valley sectors) from 1950 to 2000. A lack of stations between 48 and $51^{\circ} \mathrm{S}$ precludes analysis in this region. No statistically significant changes are revealed for the central $\left(30-38^{\circ} \mathrm{S}\right)$ and southernmost (austral, south of $52^{\circ} \mathrm{S}$ ) parts of Chile, while a decrease in precipitation does occur in the southern part between 38 and $46^{\circ} \mathrm{S}$, which is statistically significant at some stations.

The scarce precipitation records in the northern altiplano allow only a limited examination of the snowfall trends in this region. Figure 6 shows the long-term behaviour at Visviri $\left(18^{\circ} 23^{\prime} \mathrm{S}, 69^{\circ} 33^{\prime} \mathrm{W} ; 4070 \mathrm{~m}\right.$ a.s.l. $)$, which can be considered a reference station for the most northern region. 


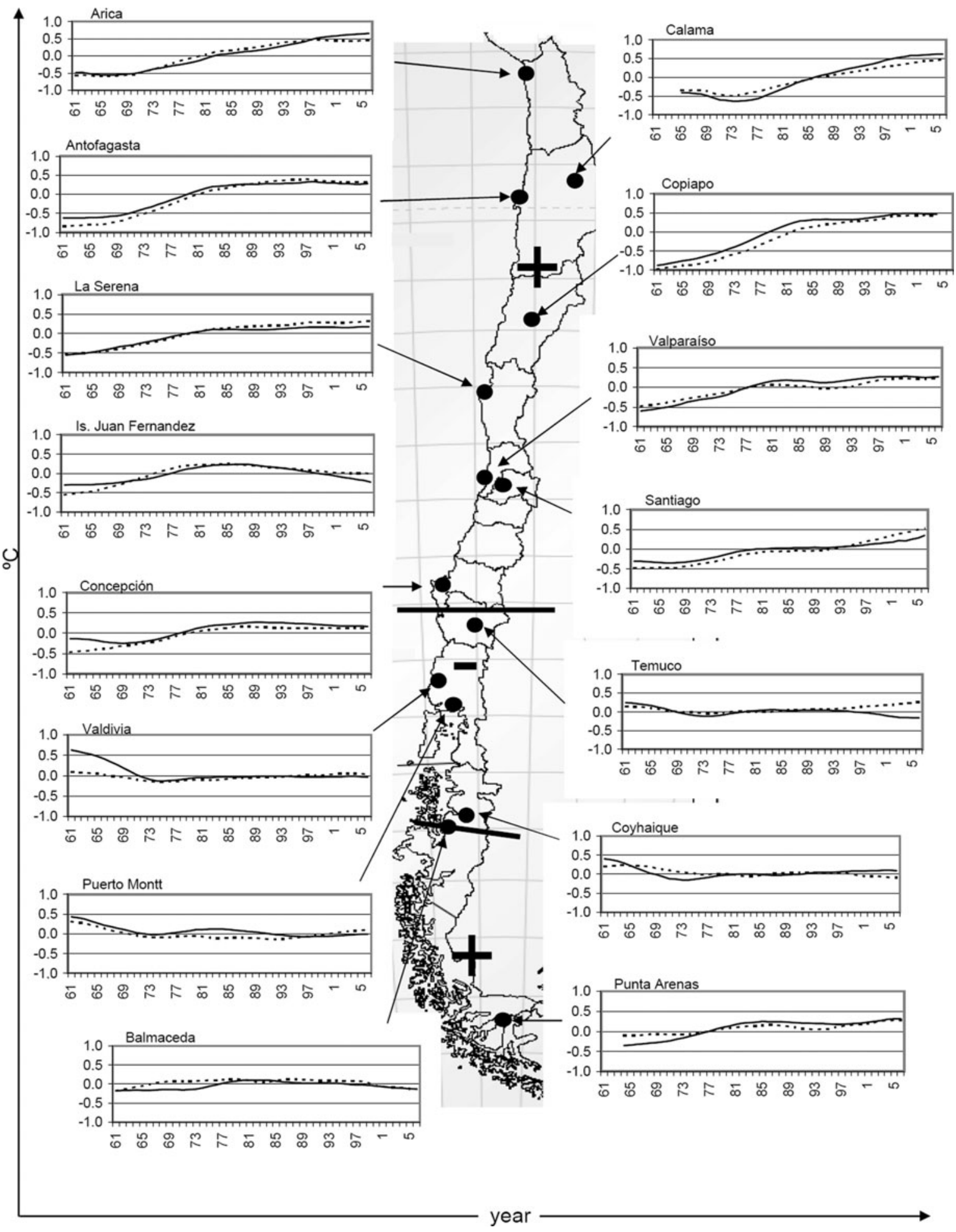

Fig. 3. Anomalies of the seasonal mean of minimum near-surface air-temperature behaviour recorded at several weather stations in Chile. Solid (dashed) curves correspond to summer (winter) season, after applying an exponential filter to the annual values. Minus and plus signs indicate near-surface cooling and warming, respectively.

An overall slight increase (not statistically significant) of $12 \pm 2 \mathrm{~mm}(10 \mathrm{a})^{-1}$ occurred in precipitation at this station during the full 1962-2003 period, although a non-significant negative trend is observed between the late 1970s and the mid-1990s, followed by an increase in precipitation thereafter. At Huatacondo station, however, a slight not statistically significant negative trend is revealed $\left(20^{\circ} 56^{\prime} \mathrm{S}\right.$, $69^{\circ} 05^{\prime} \mathrm{W} ; 2450 \mathrm{~m}$ a.s.l.) although from the mid-1990s it shows an increase in precipitation as at Visviri station.

\section{$0^{\circ} \mathrm{C}$ isotherm and ELA}

The altitude of the $0^{\circ} \mathrm{C}$ isotherm can be obtained from the daily vertical profile of the radiosonde data. This information was used to construct the monthly, seasonal and annual average at each of the three northern aerological stations from 1958 to 2006, and for Punta Arenas from 1975 to 2006. The interannual standardized anomalies and the secular trend obtained applying the exponential filter for 


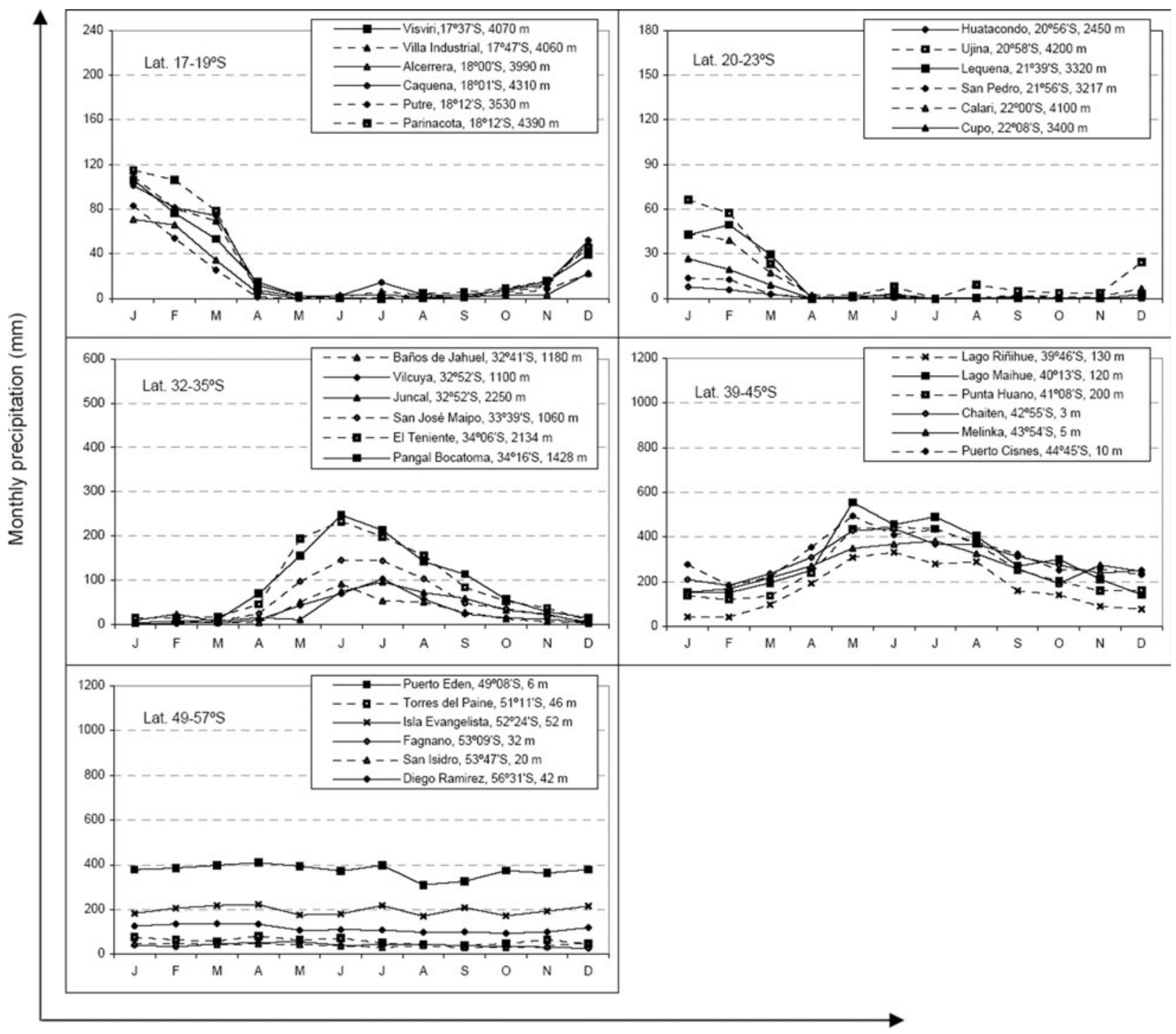

Fig. 4. Average monthly precipitation $\left(\mathrm{mm} \mathrm{a}^{-1}\right.$ ) at different locations from north to south along the Chilean Andes. All stations are located on the western side of the Andes, except for the southernmost plot where Torres del Paine, Fagnano and San Isidro are located east of the Andes. Station elevations are expressed in $\mathrm{m}$ a.s.l.

the four aerological stations are shown in Figure 7. Standardization was performed taking the average value within the period subtracted from the annual value, and divided by the standard deviation within the period. Table 3 indicates the basic statistics at each site for three periods, 1958-2006, 1958-76 and 1978-2006, except for Punta Arenas where the data cover the 1975-2006 period only. An overall positive trend can be observed, which is statistically significant (at the 95\% confidence level) in Antofagasta and Quintero/Santo Domingo. The climate shift of 1976/77 is also clearly revealed by the time series with a negative (cooling) trend before 1976 and a positive (warming) trend after 1977 (Giese and others, 2002). In fact, analysis of the mean altitudes of the $0^{\circ} \mathrm{C}$ isotherm indicates predominantly warmer conditions during the past 30 years, statistically significant (at the 95\% level), compared to the period 195876. The climate shift is associated with the PDO, which has a spatial climate pattern similar to the El Niño-Southern Oscillation (ENSO) but with a timescale of $\sim 20-30$ years (Zhang and others, 1997). A cool phase of PDO prevailed from 1947 to 1976 while a warm phase dominated from 1976 to the late 1990s.
The ELA represents the altitude where the annually integrated glacier mass balance is zero. This is closely related to the air temperature and precipitation. Above the ELA, annual net accumulation takes place, while below the ELA annual net ablation occurs. A rise (lowering) of the ELA implies loss (gain) of glacial mass which results in a subsequent retreat (advance) of the glacier front after a certain response time which depends mainly on glacier accumulation and thickness (Jóhannesson and others, 1989).

ELA data for the southern Andes are scarce, normally being measured by means of field observations and/or aerial and satellite imagery acquired at the end of the summer period. The sporadic nature of the ELA information generally precludes a time-series analysis. Here the ELA is reconstructed using a relationship between the precipitation and the altitude of the $0^{\circ} \mathrm{C}$ isotherm, based on a method first developed by Fox (1993) and Condom (2002; see also Condom and others, 2007) and modified by Carrasco and others (2005) for central Chile. First, the concept of normalized snowline altitude $\left(h_{\text {snowline }}\right)$ is introduced, defined as the difference (in $\mathrm{m}$ ) between the ELA or regional 


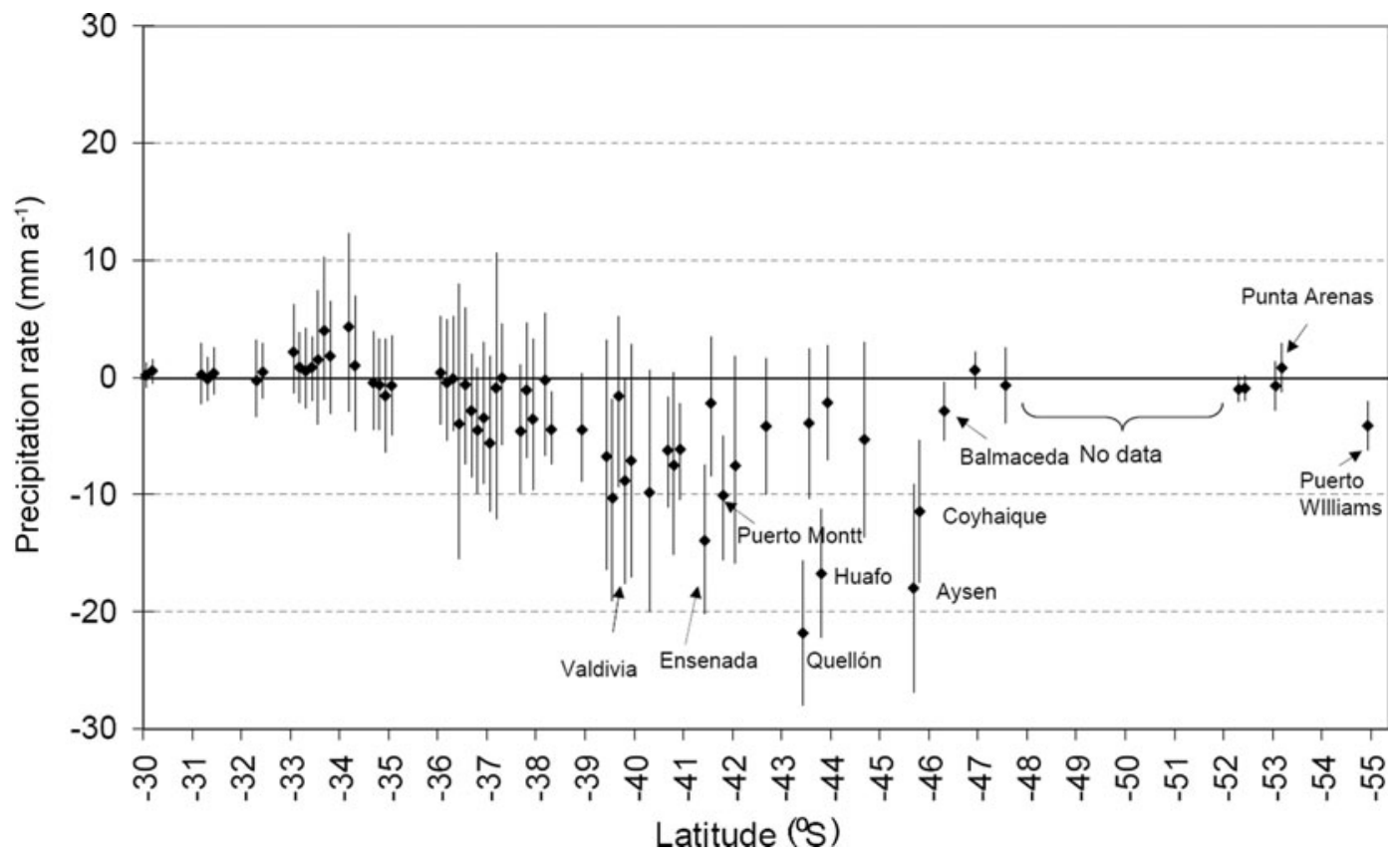

Fig. 5. Annual precipitation trend (in $\mathrm{mm} \mathrm{a}^{-1}$ ) during the period 1950-2000 for 66 rain-gauge stations located between 30 and $55^{\circ} \mathrm{S}$. Dots represent trend values in $\mathrm{mm}$ in the 50 year period, and the vertical lines across each dot are the confidence intervals calculated using the Monte Carlo test, with a significance level of 95\% (Quintana, 2004).

snowline altitude and the altitude of the mean annual $0^{\circ} \mathrm{C}$ isotherm $\left(h_{0}{ }^{\circ} \mathrm{C}\right)$ :

$$
h_{\text {snowline }}=\mathrm{ELA}-h_{0^{\circ} \mathrm{C}} .
$$

Condom (2002) and Condom and others (2007) estimate the altitude of the $0^{\circ} \mathrm{C}$ isotherm (in $\mathrm{m}$ ) from the vertical temperature gradient, which for the southern Andes is $0.65^{\circ} \mathrm{C}(100 \mathrm{~m})^{-1}$ (Aceituno, 1996). Thus,

$$
h_{0}{ }^{\circ} \mathrm{C}=\frac{T}{0.0065}+z,
$$

where $T$ is the mean annual temperature $\left({ }^{\circ} \mathrm{C}\right)$ and $z$ is the elevation $(\mathrm{m})$ of the surface station used for the calculation. Fox (1993) established an empirical relation linking the annual normalized snowline altitude $\left(h_{\text {snowline }}\right)$ and the annual precipitation $P\left(\mathrm{mma}^{-1}\right)$ measured at a nearby ground station:

$$
h_{\text {snowline }}=c_{1}-c_{2} \log { }_{10}(P) .
$$

Here, $c_{1}$ and $c_{2}$ are non-dimensional constants obtained by linear regression of the normalized snowline altitude (Equation (1)) and the logarithm of the precipitation (Fox, 1993). For this purpose Condom and others (2007) used $0^{\circ} \mathrm{C}$ isotherm altitudes derived from ground stations, an estimated temperature lapse rate and real ELA data of glaciers. They determined values of $c_{1}=3427 \mathrm{~m}$ and $c_{2}=-1148 \mathrm{~m}$, which are well constrained for the tropical Andes, whereas they only rely on a few glacier data points in the southern Andes. Combining the three equations and considering precipitation data of nearby stations, Condom and others (2007) obtained:

$$
\operatorname{ELA}(\mathrm{m})=3427-1148 \log { }_{10}(P)+\frac{T}{0.0065}+z .
$$

The temperature and precipitation dataset used by Condom and others (2007) are those of New and others (2000) for the 1961-90 period, which have a spatial resolution of $10^{\prime}$ and cover the entire globe.
Carrasco and others (2005) derived a similar expression valid for central Chile $\left(30-38^{\circ} \mathrm{S}\right)$ using the actual altitude of the $0^{\circ} \mathrm{C}$ isotherm $\left(\mathrm{H}_{0^{\circ} \mathrm{C}}\right)$ obtained from radiosonde data at Quintero/Santo Domingo, precipitation for $\sim 260$ ground stations extrapolated to $2500 \mathrm{~m}$ a.s.l. and real ELA information for eight sites between 27 and $39^{\circ} \mathrm{S}$ (Table 4). Carrasco and others (2005) obtained $c_{1}=3104.9 \mathrm{~m}$ and $c_{2}=-920.24 \mathrm{~m}$, and the expression results in:

$$
\operatorname{ELA}(\mathrm{m})=3104.9-920.24 \log { }_{10}(P)+H_{0}{ }^{\circ} \mathrm{C} \text {. }
$$

Table 2. Secular trends of the near-surface minimum air temperature $\left({ }^{\circ} \mathrm{C}(10 \mathrm{a})^{-1}\right)$ after filtering out the interannual variability. Summer (winter) corresponds to December-February (June-August). The names of the stations located inland are bold; all the others are coastal stations

\begin{tabular}{lccrr}
\hline \multirow{2}{*}{ Location } & \multicolumn{2}{c}{$1961-2006$} & \multicolumn{2}{c}{$1978-2006$} \\
& Summer & Winter & Summer & Winter \\
& & & & \\
\hline Arica & $0.31^{*}$ & $0.29^{*}$ & 0.23 & 0.05 \\
Calama & $0.31^{*}$ & $0.26^{*}$ & 0.34 & 0.21 \\
Antofagasta & $0.26^{*}$ & $0.30^{*}$ & -0.08 & -0.01 \\
Copiapó & $0.35^{*}$ & $0.38^{*}$ & -0.07 & 0.06 \\
La Serena & $0.17^{*}$ & $0.21^{*}$ & -0.06 & 0.01 \\
Valparaíso & $0.20^{*}$ & $0.15^{*}$ & -0.01 & -0.03 \\
Santiago & $0.17^{*}$ & $0.22^{*}$ & 0.04 & 0.11 \\
Is. Juan Fernández & 0.06 & 0.12 & -0.23 & -0.22 \\
Concepción & 0.12 & 0.15 & -0.01 & -0.08 \\
Temuco & -0.04 & 0.04 & -0.14 & 0.05 \\
Valdivia & -0.10 & -0.01 & -0.04 & 0.04 \\
Puerto Montt & -0.07 & -0.04 & -0.01 & 0.02 \\
Coyhaique & -0.01 & -0.06 & -0.04 & -0.02 \\
Balmaceda & 0.03 & 0.00 & 0.19 & -0.01 \\
Punta Arenas & 0.15 & 0.08 & 0.08 & -0.03 \\
& & & & \\
\hline
\end{tabular}

*Significant at $95 \%$. 

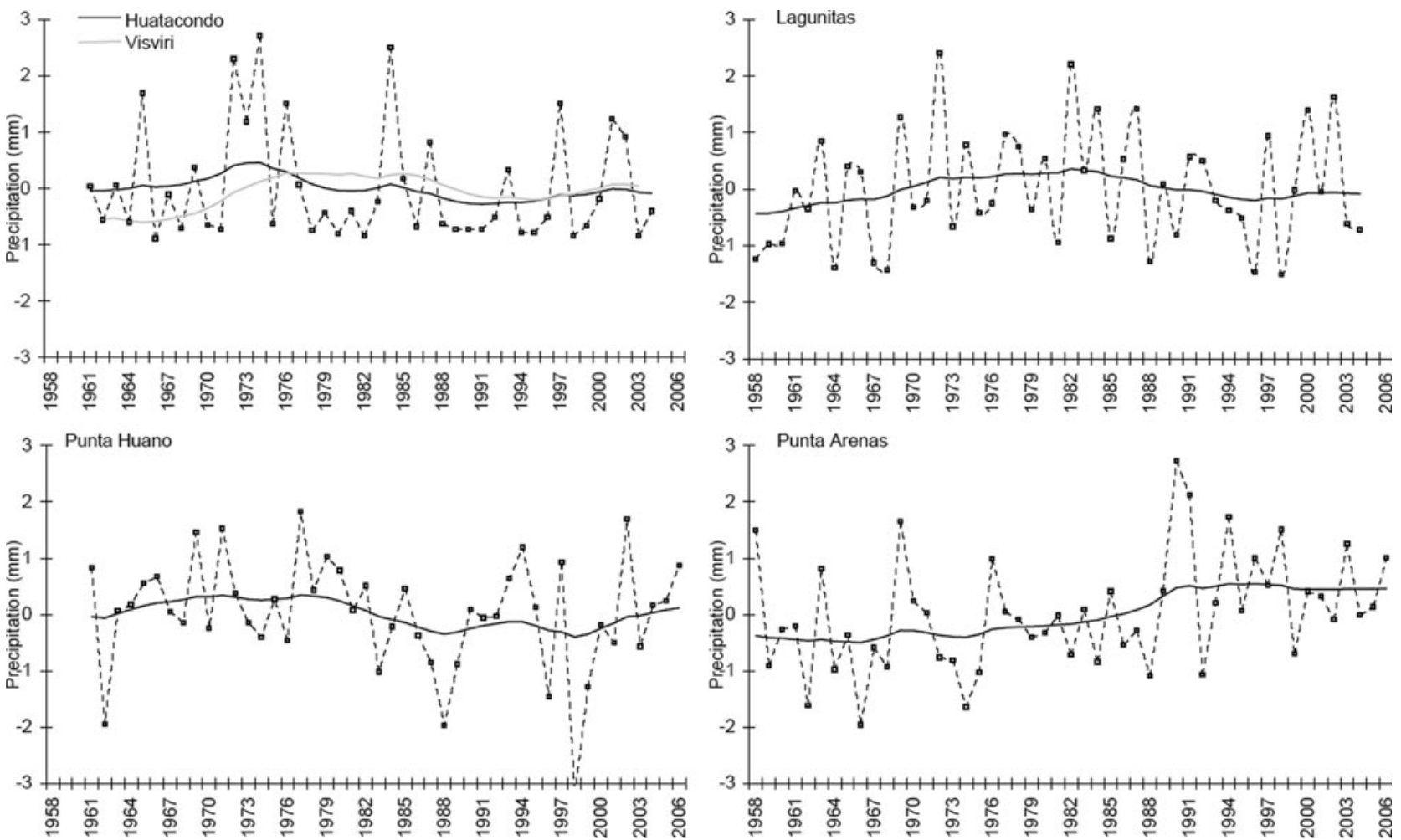

Fig. 6. Standardized anomalies of the interannual mean (dashed curves) and secular trend (solid curves) obtained after applying an exponential filter for annual precipitation at Visviri/Huatacondo, Lagunitas, Punta Huano and Punta Arenas stations which, respectively, are locations close to the radiosonde stations Antofagasta, Quintero/Santo Domingo, Puerto Montt and Punta Arenas.

Figure 8 shows the original north-south ELA profile reproduced from Condom and others (2007), along with the altitude of the $0^{\circ} \mathrm{C}$ isotherm. Superposed are the ELAs calculated using the expressions of Condom and others (2007) and Carrasco and others (2005), which correspond to Equations (4) and (5), respectively, computed at five latitudinal locations along the Chilean Andes: Visviri, Huatacondo, Quintero/Santo Domingo, Puerto Montt and Punta Arenas. Also shown in Figure 8 and Table 4 are ELA data available from remote-sensing studies and ground information, which are used to compare the different ELA models.
In the northern region (region 1 in Fig. 8), the most complete precipitation time series available are for Visviri $\left(17^{\circ} 37^{\prime} \mathrm{S}, 69^{\circ} 30^{\prime} \mathrm{W} ; 4070 \mathrm{~m}\right.$ a.s.l.) and Huatacondo $\left(20^{\circ} 56^{\prime} \mathrm{S}, 69^{\circ} 05^{\prime} \mathrm{W} ; 2450 \mathrm{~m}\right.$ a.s.l.), and for air temperature it is data from Calama $\left(22^{\circ} 29^{\prime} \mathrm{S}, 68^{\circ} 54^{\prime} \mathrm{W} ; 2270 \mathrm{~m}\right.$ a.s.l.). Applying Condom's expression (Equation (4)), we obtained an ELA of $4678 \pm 412 \mathrm{~m}$ using Visviri precipitation and $6565 \pm 693 \mathrm{~m}$ using Huatacondo. Error estimates here represent one standard deviation.

The same exercise was conducted introducing into Equation (4) the mean annual air temperature and geopotential

Table 3. Altitude (ma.s.I.) and tendency $\left(\mathrm{m}(10 \mathrm{a})^{-1}\right)$ of the $0^{\circ} \mathrm{C}$ isotherm for different periods

\begin{tabular}{|c|c|c|c|c|c|c|}
\hline \multirow[t]{2}{*}{ Location } & \multicolumn{2}{|c|}{ 1958-2006 } & \multicolumn{2}{|c|}{ 1958-76 } & \multicolumn{2}{|c|}{ 1978-2006 } \\
\hline & $\begin{array}{c}\text { Average altitude } \\
\quad \text { (std dev.) }\end{array}$ & $\begin{array}{l}\text { Tendency } \\
\text { (std error) }\end{array}$ & $\begin{array}{c}\text { Average altitude } \\
\text { (std dev.) }\end{array}$ & $\begin{array}{l}\text { Tendency } \\
\text { (std error) }\end{array}$ & $\begin{array}{c}\text { Average altitude } \\
\text { (std dev.) }\end{array}$ & $\begin{array}{l}\text { Tendency } \\
\text { (std error) }\end{array}$ \\
\hline Antofagasta & $\begin{array}{c}4573 \\
(57)\end{array}$ & $\begin{array}{l}39^{*} \\
( \pm 2)\end{array}$ & $\begin{array}{c}4497 \\
(11)\end{array}$ & $\begin{array}{l}-18^{*} \\
( \pm 1)\end{array}$ & $\begin{array}{c}4622 \\
(36)\end{array}$ & $\begin{array}{l}42^{*} \\
( \pm 1)\end{array}$ \\
\hline Quintero/Santo Domingo & $\begin{array}{c}3584 \\
(34)\end{array}$ & $\begin{array}{l}23^{*} \\
( \pm 1)\end{array}$ & $\begin{array}{c}3533 \\
(11)\end{array}$ & $\begin{array}{l}-19^{*} \\
( \pm 2)\end{array}$ & $\begin{array}{c}3613 \\
(16)\end{array}$ & $\begin{array}{l}19^{*} \\
( \pm 1)\end{array}$ \\
\hline Puerto Montt & $\begin{array}{c}2278 \\
(37)\end{array}$ & $\begin{array}{l}24^{*} \\
( \pm 1)\end{array}$ & $\begin{array}{c}2213 \\
(18)\end{array}$ & $\begin{array}{l}-29^{*} \\
( \pm 3)\end{array}$ & $\begin{array}{c}2325 \\
(6)\end{array}$ & $\begin{array}{c}2 \\
( \pm 1)\end{array}$ \\
\hline Punta Arenas & $\begin{array}{c}1037^{\dagger} \\
(10)\end{array}$ & $\begin{array}{c}7^{\dagger} \\
( \pm 1)\end{array}$ & - & - & - & - \\
\hline
\end{tabular}

*Significant at 95\%.

${ }^{\dagger}$ For Punta Arenas the period is 1975-2006. 

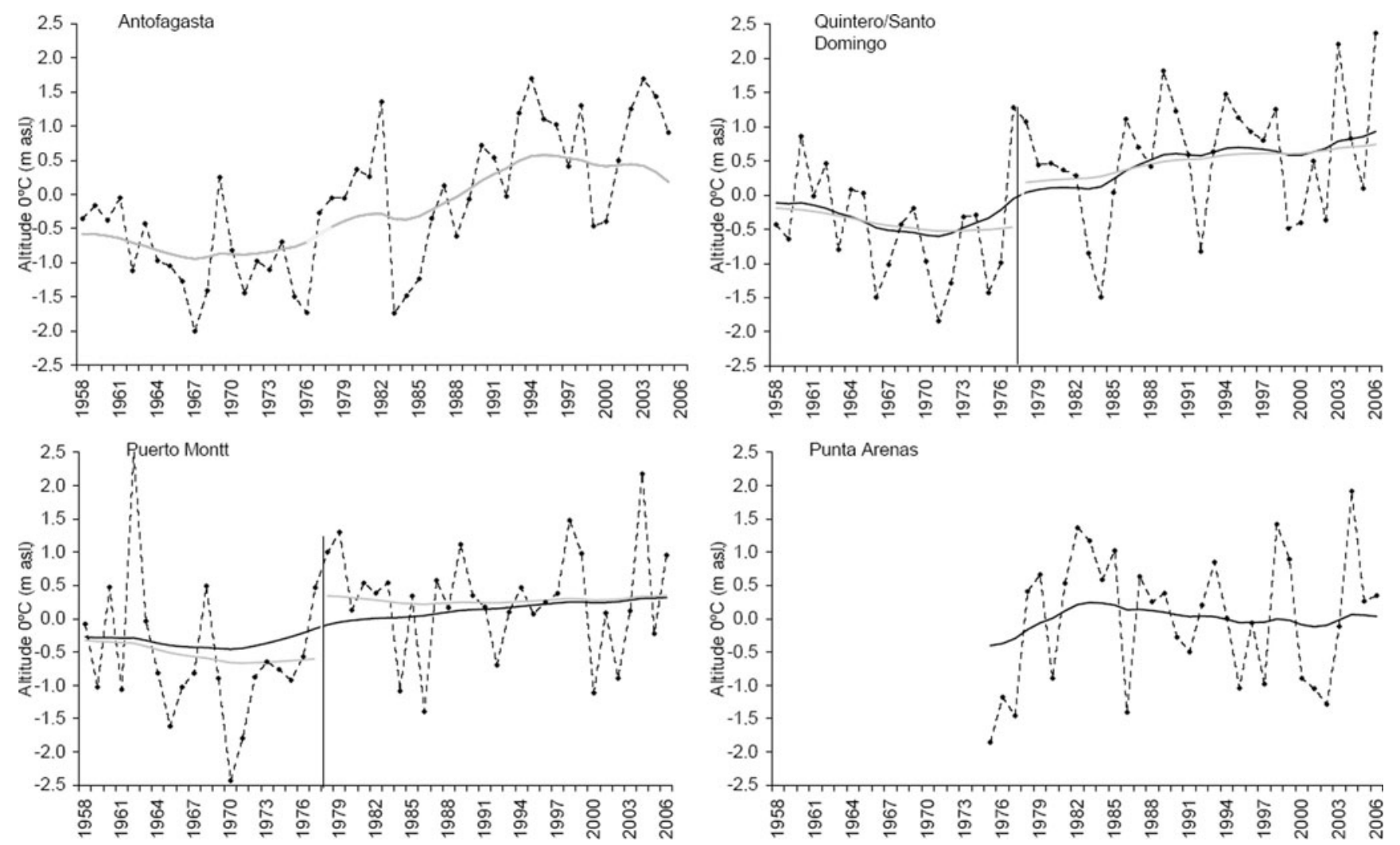

Fig. 7. Standardized anomalies of the interannual mean (dashed curves) and secular trend (solid black curves) obtained after applying an exponential filter for annual anomalies of the altitude of the $0^{\circ} \mathrm{C}$ isotherm at radiosonde stations Antofagasta, Quintero/Santo Domingo, Puerto Montt and Punta Arenas. Grey curves show the secular trends before and after the 1976/77 climate shift (vertical line).

altitude observed at the $850 \mathrm{hPa}$ level as temperature $(T)$ and elevation $(z)$ instead of the surface station data. In this case the results were $4713 \pm 245 \mathrm{~m}$ for Visviri and $6495 \pm 717 \mathrm{~m}$ for Huatacondo. The original calculation by Condom and others (2007) shows ELA values of $5800 \mathrm{~m}$ for Visviri and $4950 \mathrm{~m}$ for Huatacondo, both altitudes corresponding to the western side of the Andes. Now, applying the relationship of Carrasco and others (2005) indicated in Equation (5), where the altitude of the $0^{\circ} \mathrm{C}$ isotherm is used, the results obtained for the ELA were $5423 \pm 194 \mathrm{~m}$ for Visviri and $6850 \pm 575 \mathrm{~m}$ for Huatacondo.

For the central, southern and austral regions (regions 2, 3 and 4 , respectively) we used station data from Santiago $\left(33^{\circ} 26^{\prime} \mathrm{S}, 70^{\circ} 40^{\prime} \mathrm{W} ; 520 \mathrm{~m}\right.$ a.s.l.) (region 2), Puerto Montt (region 3) and Punta Arenas (region 4) to calculate the ELA. Applying the relationship (Equation (4)) of Condom and others (2007) we obtained $3369 \pm 257 \mathrm{~m}$ for region 1, $1350 \pm 101 \mathrm{~m}$ for region 2 and $1409 \pm 105 \mathrm{~m}$ for region 3 . The original calculation by Condom and others (2007) indicates ELA values of 4150, 2250 and $600 \mathrm{~m}$ for regions 2, 3 and 4, respectively. Now, using the $850 \mathrm{hPa}$ radiosonde data, the ELAs were $4061 \pm 274,1468 \pm 149$ and $1560 \pm 123 \mathrm{~m}$. Calculating the ELAs using the expression (Equation (5)) of Carrasco and others (2005), we found altitudes of $3954 \pm 236,2011 \pm 172$ and $991 \pm 124 \mathrm{~m}$ for regions 2, 3 and 4, respectively.

The correlation coefficients between ELAs obtained applying the expressions of Condom and others (2007) using radiosonde data as input values, and those obtained from the expression of Carrasco and others (2005) using temperature from radiosonde data and precipitation from mountain areas, were statistically significant (at 95\%) and above 0.95 in all regions. This suggests that even though there are differences in altitude from the calculated ELAs, the annual variability and tendencies are similar.

Inspection of Figure 8 shows that south of $27^{\circ} \mathrm{S}$ the model which best fits the available ELA data from existing studies is that of Carrasco and others (2005) using the $0^{\circ} \mathrm{C}$ isotherm from radiosonde data and precipitation data extrapolated to $2500 \mathrm{~m}$. Between 19 and $26^{\circ} \mathrm{S}$ there are virtually no glaciers along the Chilean Andes due to dry conditions in the so-called 'arid diagonal', with only a few rock glaciers, particularly on southern slopes. At the latitude of Huatacondo the highest mountains reach altitudes of $\sim 6500 \mathrm{~m}$, and $>6700 \mathrm{~m}$ a few hundred kilometres to the south. Similar to the regions south of $27^{\circ} \mathrm{S}$, in the area between 19 and $26^{\circ} \mathrm{S}$ the model of Carrasco and others (2005) is regarded as the best for simulating the ELA since it is the model that predicts the highest ELAs, with altitude values higher than the existing peaks, as expected. In the northernmost portion of region 1 , the highest estimate of the ELA is provided by the original results of Condom and others (2007), who predict an ELA of $5800 \mathrm{~m}$. This model of Condom and others is regarded as the best ELA prediction in the northernmost area since local glaciers, notably at Parinacota and Pomerape, have a relief ranging from $\sim 6300$ to $\sim 5300 \mathrm{~m}$ on southern slopes and down to $\sim 5800 \mathrm{~m}$ on northern slopes.

Figure 9 shows the standardized anomalies of annual variability and secular trends of the ELA using the expression of Carrasco and others (2005) with the radiosonde data and the precipitation data as described below. Table 5 summarizes statistics of mean altitude and tendency of the ELA for three periods, 1958-2006, 1958-76 and 


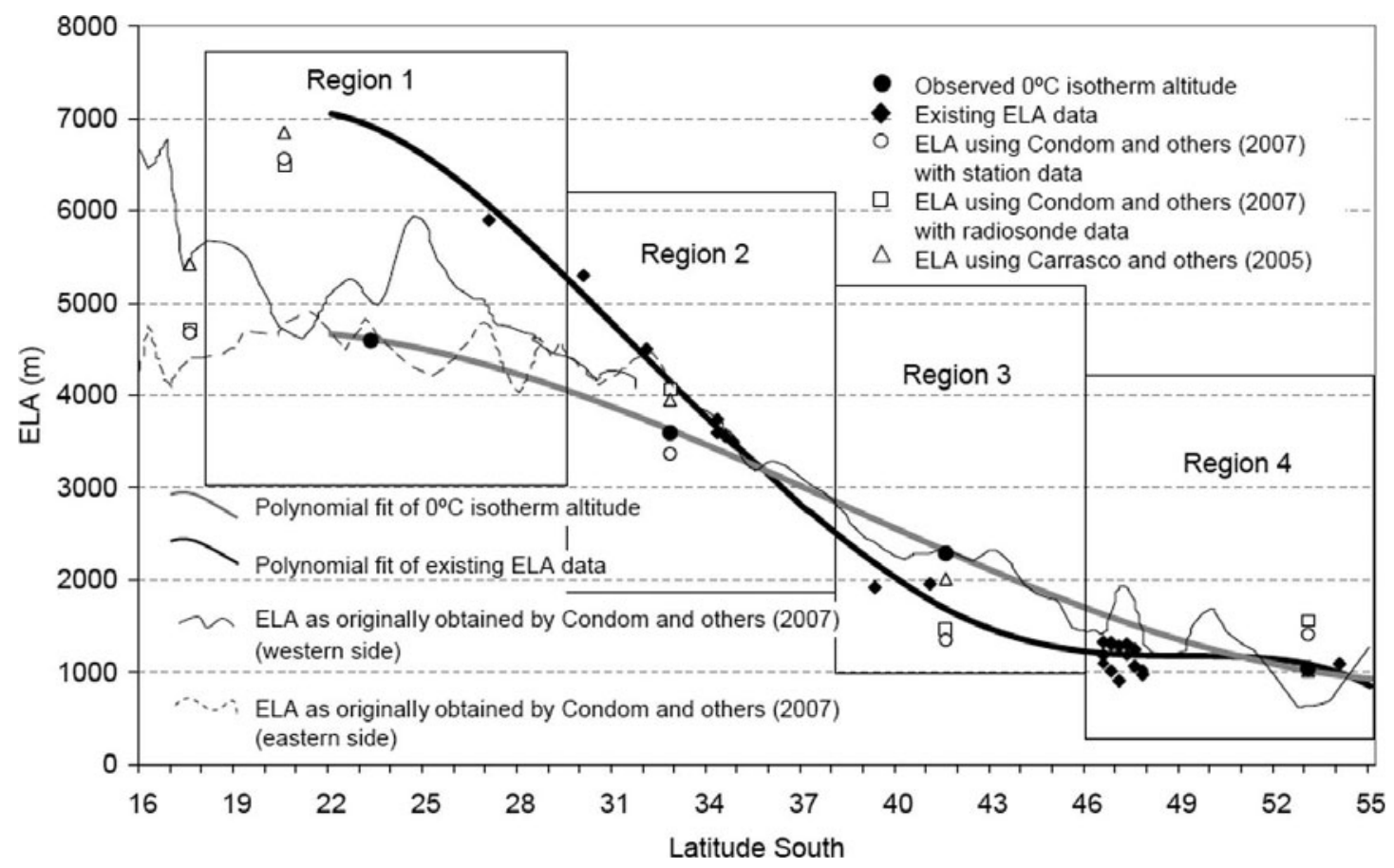

Fig. 8. ELA as calculated originally by Condom and others (2007), from their figure 3. Also plotted are the ELA obtained using the expression of Condom and others (2007) using the annual mean air temperature $(T)$ and geopotential height $(z)$ at $850 \mathrm{hPa}$ from radiosonde and precipitation data from the closest station, also calculated from ground-station data, as mentioned in the text. For the model of Carrasco and others (2005), the $0^{\circ} \mathrm{C}$ isotherm elevation was used in combination with precipitation data from ground stations, as described in the text. The latitudinal profile of the $0^{\circ} \mathrm{C}$ isotherm altitude is also plotted, based on radiosonde data for four stations, and a polynomial fit. Black diamonds are observed ELAs from existing data (Table 4).

1978-2006, except for Punta Arenas which is given only for the 1975-2006 period.

For the northern region the precipitation data correspond to Huatacondo station, which is regarded as representative for the altiplano in northern Chile. Our analysis shows that an ELA decrease took place until around 1976 and increased thereafter, with a more significant increase from 1985 to 1995. Linear regression over the period 1962-2003 indicates a positive trend of $68 \pm 12 \mathrm{~m}(10 \mathrm{a})^{-1}$.

Precipitation in central Chile is obtained from the mountain station Lagunitas $\left(33^{\circ} 04^{\prime} \mathrm{S}, 70^{\circ} 15^{\prime} \mathrm{W} ; 2765\right.$ ma.s.I.), which shows an overall positive trend of $27 \pm 6 \mathrm{~mm}(10 \mathrm{a})^{-1}$ during the period 1958-2004, with a significant increase at the $95 \%$ level from 1958 to $1982\left(170 \pm 8 \mathrm{~mm}(10 \mathrm{a})^{-1}\right)$, and a significant decline at the $95 \%$ level $\left(92 \pm 16 \mathrm{~mm}(10 \mathrm{a})^{-1}\right)$ in precipitation after 1982. Based on the Lagunitas precipitation data and temperature data at $850 \mathrm{hPa}$ for Quintero/ Santo Domingo, the ELA shows a negative trend (i.e. decreasing) from 1958 to the mid-1970s and a positive trend (i.e. increasing) thereafter. The linear ELA trend (not statistically significant) in the period 1958-2004 is $11 \pm 3 \mathrm{~m}(10 \mathrm{a})^{-1}$.

In the southern region there is no precipitation record in mountain areas, so annual data from Punta Huano $\left(41^{\circ} 08^{\prime} \mathrm{S}\right.$, $72^{\circ} 17^{\prime} \mathrm{W} ; 200 \mathrm{~m}$ a.s.I.) were used for the ELA calculation, applying a correction factor of 1.5 for the orographic effect (Adam and others, 2006). A statistically significant (at 95\%) lineal decrease in precipitation of $51 \pm 4 \mathrm{~mm}(10 \mathrm{a})^{-1}$ in the 1958-2004 period has taken place at this station. The precipitation decline in this region (Fig. 5), in addition to the increase in the $0^{\circ} \mathrm{C}$ isotherm altitude, results in a positive trend of the ELA after 1970. The overall linear rise of the ELA is $34 \pm 2 \mathrm{~m}(10 \mathrm{a})^{-1}$ for the $1959-2004$ period, which is statistically significant.

In the austral region, the annual precipitation record from Punta Arenas, located on the leeward side of the mountains, shows a linear trend of $17 \pm 1 \mathrm{~mm}(10 \mathrm{a})^{-1}$ for the period 1958-2006, which is not statistically significant. The annual precipitation at this site was multiplied by a factor of 6.7 according to the ratio in the annual precipitation with respect to Faro Evangelistas station located on the coastal side, windward from the Andes, which is regarded as being more representative of precipitation of the mountain glacier areas (Schneider and others, 2003). The result is a significant (at the 95\% level) increase in precipitation during the 19582006 period of $112 \pm 4 \mathrm{~mm}(10 \mathrm{a})^{-1}$, with a corresponding ELA lowering of $8 \pm 2 \mathrm{~m}(10 \mathrm{a})^{-1}$ during the 1975-2006 period of available radiosonde data.

Comparing the values given in Tables 3 and 5 for regions 1, 2 and 3, it can be seen that the mean ELA values before the 1976/77 climate shift are lower than the mean obtained for the 1978-2006 period, with a statistically significant difference (at 95\% level) between the 1958-76 average and the 1978-2006 average. Also, the linear tendencies change from a negative trend before the shift to a positive trend after the shift. These results indicate the influence of the PDO on the air temperature and on the ELA's behaviour.

\section{DISCUSSION AND CONCLUSIONS}

According to surface air-temperature records from valley and coastal stations, a significant warming has occurred from 1961 onward in northern (region 1) and central 

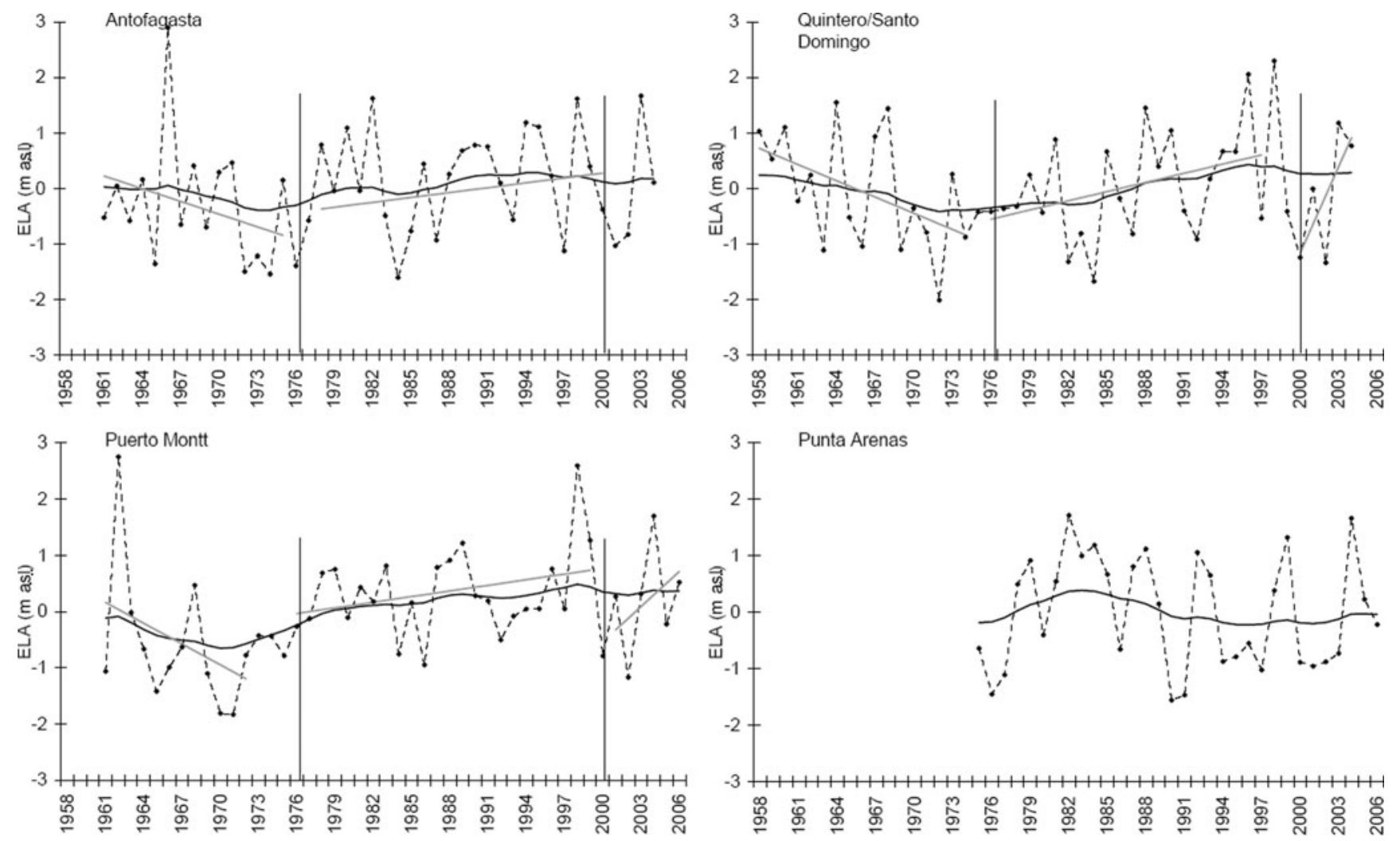

Fig. 9. Standardized anomalies of the interannual mean (dashed curves) and secular trend (solid curves) obtained after applying an exponential filter of the derived ELAs at the radiosonde stations Antofagasta, Quintero/Santo Domingo, Puerto Montt and Punta Arenas. Grey lines show the secular trends before and after the 1976/77 climate shift (vertical line) and the year 2000.

(region 2) Chile. In the southern region (region 3) there is a slight cooling, with a non-significant warming in the austral region (region 4 ). In the lower troposphere, as revealed by the $850 \mathrm{hPa}$ level of the radiosonde profiles, there is significant warming at all stations except Punta Arenas.

The air-temperature behaviour is strongly forced in all regions by the climate shift that took place in the mid-1970s, mainly in the central and southern regions. Data analysis from surface stations indicates a slight cooling observed at coastal surface stations (mainly in summer) between Antofagasta and Coyhaique (Table 2) after 1976/77. According to radiosonde air-temperature data at $850 \mathrm{hPa}$, the cooling is restricted to the near-surface troposphere and probably within the boundary layer, below 800-1000 m.

An evaluation of the air temperatures obtained from the radiosonde data at $850 \mathrm{hPa}$ for the 1958-2006 period indicates a significant increase (95\% level) of $0.22 \pm$ $0.01^{\circ} \mathrm{C}(10 \mathrm{a})^{-1}$ in Antofagasta, $0.15 \pm 0.10^{\circ} \mathrm{C}(10 \mathrm{a})^{-1}$ in Quintero/Santo Domingo and $0.12 \pm 0.10^{\circ} \mathrm{C}(10 \mathrm{a})^{-1}$ in Puerto Montt (not statistically significant). Although the annual warming at Puerto Montt is not significant, in winter (summer) there is a significant warming of $0.14^{\circ} \mathrm{C}\left(0.13^{\circ} \mathrm{C}\right)$.

There is an overall positive trend in ELA in regions 1,2 and 3 for the study period 1958-2006. In region 4 there is no trend in the ELA for the same period. Before the 1976/77 climate shift the ELAs show a statistically significant (at 95\%) negative linear trend. By contrast, after this date, the ELAs present a significant positive trend until 1998-99 in the central and southern regions (regions 2 and 3), and a nonsignificant positive trend in the northern region (region 1 ). In the austral region (region 4) there is a slight ELA decrease after 1982. Both central and southern regions show a significant ELA decline between 1998 and 2000 (Fig. 9) and thereafter a significant positive trend took place.

As reported by Rivera and others (2006), glaciers in the central region (region 2) showed a significant ice-mass reduction with an accelerating trend in recent decades (Fig. 1). In this region, the annual mass balance is closely related to the ENSO. During the warm El Niño (cold La Niña) phase, winter precipitation is likely to be higher (lower) than normal and consequently the mass balance is likely to be positive (negative). This has been recorded by the systematic measurements at Glaciar Echaurren Norte $\left(33^{\circ} 35^{\prime} \mathrm{S}, 70^{\circ} 08^{\prime} \mathrm{W}\right)$ by the Dirección General de Aguas (Escobar and others, 1995). Although mass-balance data from this glacier show a net positive balance for the 197393 period (Escobar and others, 1995), updated analysis reveals a clearly negative trend (Casassa and others, 2006) after 1988. The overall glacier retreat and thinning in the central Chilean Andes concurs with the overall ELA increase found in our analysis.

The ELA behaviour in the southern region concurs with the maximum decrease of the ice-mass area in the most recently analyzed period observed by Rivera and others (2005), who reported a loss of $0.45 \mathrm{~km}^{2} \mathrm{a}^{-1}$ between 1987 and 2003 at glaciers on Volcán Mocho-Coshuenco (39 55' S, $\left.72^{\circ} 02^{\prime} \mathrm{W}\right)$. This enhanced mass loss in recent years is confirmed by Bown and Rivera (2007) who found an areal change in Glaciar Casa Pangue $\left(41^{\circ} 08^{\prime} \mathrm{S}, 71^{\circ} 52^{\prime} \mathrm{W}\right)$ ranging from $-0.19 \mathrm{~km}^{2}$ for the $1961-81$ period to $-0.47 \mathrm{~km}^{2}$ for the 1981-98 period, and a frontal variation of -10 to $-51 \mathrm{~m} \mathrm{a}^{-1}$ for the respective periods.

In the austral region $\left(\sim 46-55^{\circ} \mathrm{S}\right)$ an ELA lowering of $8 \pm 1 \mathrm{~m}(10 \mathrm{a})^{-1}$ in the period $1975-2006$ is modelled in this 
Table 4. Available ELA data for the Chilean Andes from existing published sources. The ELA data are used in Figure 8 for comparing the different model predictions. The column labelled ${ }^{* *}$ indicates whether the ELA data were used for calibrating the ELA model of Carrasco and others (2005)

\begin{tabular}{|c|c|c|c|c|c|}
\hline Glacier & $\begin{array}{l}\text { Lat. } \\
{ }^{\circ} \mathrm{S}\end{array}$ & $\begin{array}{l}\text { Long. } \\
{ }^{\circ} \mathrm{W}\end{array}$ & $\begin{array}{c}\text { ELA } \\
\mathrm{m}\end{array}$ & $* *$ & Source \\
\hline - & 27.00 & - & 5900 & yes & 1 \\
\hline - & 30.00 & - & 5300 & yes & 1 \\
\hline - & 32.00 & - & 4500 & yes & 1 \\
\hline Palomo & 34.23 & 70.13 & 3596 & yes & 3 \\
\hline Cortaderal & 34.26 & 70.13 & 3740 & yes & 3 \\
\hline Cipreses & 34.55 & 70.37 & 3559 & yes & $2 \& 3$ \\
\hline Universidad & 34.70 & 70.33 & 3497 & yes & $2 \& 3$ \\
\hline Mocho & 39.23 & 72.03 & 1920 & yes & 4 \\
\hline Casa Pangue & 41.13 & 71.87 & 1958 & no & $2 \& 6$ \\
\hline Grosse & 46.45 & 72.30 & 1096 & no & $5 \& 7$ \\
\hline Rio Verde & 46.47 & 73.38 & 1257 & no & 5 \\
\hline Reicher & 46.48 & 73.92 & 1328 & no & $5 \& 7$ \\
\hline Exploradores & 46.50 & 73.17 & 1187 & no & $5 \& 7$ \\
\hline Gualas & 46.55 & 73.67 & 1087 & no & $5 \& 7$ \\
\hline San Rafael & 46.68 & 73.85 & 1013 & no & $2 \& 7$ \\
\hline Fiero & 46.70 & 73.20 & 1294 & no & $5 \& 7$ \\
\hline Leones & 46.77 & 73.22 & 1322 & no & $5 \& 7$ \\
\hline San Quintín & 46.87 & 74.08 & 957 & no & $2 \& 7$ \\
\hline Soler & 46.90 & 73.18 & 1283 & no & $5 \& 7$ \\
\hline Benito & 47.03 & 73.90 & 908 & no & $5 \& 7$ \\
\hline Cachet & 47.10 & 73.20 & 1303 & no & $5 \& 7$ \\
\hline Nef & 47.12 & 73.18 & 1183 & no & $5 \& 7$ \\
\hline HPN 1 & 47.18 & 73.87 & 959 & no & $5 \& 7$ \\
\hline Colonia & 47.25 & 73.23 & 1302 & no & $5 \& 7$ \\
\hline Arco & 47.28 & 73.28 & 1248 & no & $5 \& 7$ \\
\hline Pared Sur & 47.45 & 73.42 & 975 & no & $5 \& 7$ \\
\hline Pared Norte & 47.47 & 73.33 & 1025 & no & $5 \& 7$ \\
\hline Piscis & 47.48 & 73.25 & 1065 & no & $5 \& 7$ \\
\hline Steffen & 47.53 & 73.70 & 1074 & no & $5 \& 7$ \\
\hline Martial Este & 54.78 & 68.40 & 1090 & no & 8 \\
\hline
\end{tabular}

Sources: 1: Hastenrath (1971); 2: Rivera and others (2000); 3: Lequesne (personal communication, 2005, quoted in Carrasco and others, 2005); 4: Rivera and others (2005); 5: Aniya (1988); 6: Bown (2004); 7: Rivera and others (2007); 8: Strelin and Iturraspe (2007).

study due to a slight increase in precipitation and a decrease in the $0^{\circ} \mathrm{C}$ isotherm altitude. An ELA lowering is not evident in this region based on the extensive observations of glacierfront positions and glacier thinning available, for example, for the Patagonian icefields (e.g. Rignot and others, 2003), Gran Campo Nevado (Schneider and others, 2003), northern Cordillera Darwin (Holmlund and Fuenzalida, 1995; Porter and Santana, 2003) and eastern Cordillera Darwin (Strelin and Iturraspe, 2007), all of which show strong and increased glacier wasting in recent years. Only in the southwestern Cordillera Darwin are many glaciers growing (Holmlund and Fuenzalida, 1995), with advancing fronts at least until January 2007 according to a field visit made to the area by one of the authors (G.C.). Therefore, the combination of the radiosonde data at Punta Arenas and the precipitation data at Faro Evangelistas is either not representative for the prevailing glacier conditions in Patagonia and Tierra del Fuego, or perhaps the Fox-Condom parameterization of the ELA performed in this study is not valid for this particular region.

A lack of precipitation trends in western Patagonia for the last 40 years is suggested by analysis of upper-air US National Centers for Environmental Prediction-US National
Center for Atmospheric Research (NCEP-NCAR) data (Rasmussen and others, 2007), although a positive trend has been detected in the Southern Annular Mode (Marshall and others, 2004) during the last few decades which should translate into an intensification of the westerlies and an accompanying precipitation increase. There seems to be a non-negligible warming signal in Patagonia in recent decades based on the NCEP-NCAR analysis of Rasmussen and others (2007) and data from Argentine stations (Ibarzabal and others, 1996). In a study of Gran Campo Nevado $\left(53^{\circ} \mathrm{S}\right)$, Moeller and others (2007) detected an average thinning of glaciers greater than $1 \mathrm{ma}^{-1}$ at low elevation and a small but significant thickening at higher elevations, resulting in an overall net thinning, which they explain as a result of a combined increase in precipitation and warming.

In the northern $\left(\sim 18-30^{\circ} \mathrm{S}\right)$ and central $\left(\sim 30-38^{\circ} \mathrm{S}\right)$ parts of the Andes in Chile, there is no significant change in precipitation after the $1976 / 77$ climate shift; at the same time a significant (at 95\%) positive trend of the $0^{\circ} \mathrm{C}$ isotherm (Table 3) has occurred, indicating that the ELA rise in these regions is likely to be due to warming only. In the southern region $\left(\sim 38-46^{\circ} \mathrm{S}\right)$ there has been a significant decrease in precipitation (Fig. 4), with a significant winter and summer increase in the $0^{\circ} \mathrm{C}$ isotherm, suggesting that the ELA rise is due both to precipitation decline and warming.

Our radiosonde data for the southern region indicate that the mid-elevation surface-warming signal in the Andes is not reflected by the slight cooling trend observed at sea level. The same conclusion was drawn by Vuille and Bradley (2000) for the tropical Andes, where there is significant warming at high altitudes but slight cooling in the lower troposphere. A lower-troposphere warming which increases with altitude is predicted by general circulation models under scenarios of enhanced concentration of greenhouse gases (Bradley and others, 2006). Therefore we should expect that glaciers located in the high Andes will be especially affected by future warming.

This study has shown that except for the northernmost area of Chile $\left(\sim 18^{\circ} \mathrm{S}\right)$ and in the Patagonia-Tierra del Fuego region $\left(\sim 46-55^{\circ} \mathrm{S}\right)$, the radiosonde data along with precipitation records of surface stations can be useful in reconstructing a time series of ELA information for application in glaciological studies. The ELA model can be applied to project the effect of predicted climate changes on the future condition of glaciers, which are important sources of water and can also present increased hazards under warming scenarios.

\section{ACKNOWLEDGEMENTS}

This study was funded by Comisión Nacional de Investigación Científica y Tecnológica de Chile through FONDECYT Projects 1040989 and 1061269, and Proyecto Anillo, PBCT ACT-19. Centro de Estudios Científicos (CECS) is funded by the Chilean Government through the Millennium Science Initiative and the Centers of Excellence Base Financing Program of CONICYT (Comision Nacional de Investigacion Cientifica y Technologica de Chile). CECS is also supported by a group of private companies which at present includes Antofagasta Minerals, Arauco, Empresas CMPC, Indura, Naviera Ultragas and Telefónica del Sur. Figure 3 was provided by J. Quintana of the Dirección Meteorológica de Chile. F. Ordenes from CECS provided help with the figures. 
Table 5. Altitude (m a.s.l.) and tendency $\left(\mathrm{m}(10 \mathrm{a})^{-1}\right)$ of the ELA for different periods after filtering the annual variability using an exponential filter

\begin{tabular}{|c|c|c|c|c|c|c|}
\hline \multirow[t]{2}{*}{ Location } & \multicolumn{2}{|c|}{ 1958-2006 } & \multicolumn{2}{|c|}{$1958-76$} & \multicolumn{2}{|c|}{ 1978-2006 } \\
\hline & $\begin{array}{c}\text { Average altitude } \\
\text { (std dev.) }\end{array}$ & $\begin{array}{l}\text { Tendency } \\
\text { (std error) }\end{array}$ & $\begin{array}{c}\text { Average altitude } \\
\quad \text { (std dev.) }\end{array}$ & $\begin{array}{l}\text { Tendency } \\
\text { (std error) }\end{array}$ & $\begin{array}{l}\text { Average altitude } \\
\quad \text { (std dev.) }\end{array}$ & $\begin{array}{l}\text { Tendency } \\
\text { (std error) }\end{array}$ \\
\hline Antofagasta & $\begin{array}{l}6502 \\
(135)\end{array}$ & $\begin{array}{c}11 \\
( \pm 4)\end{array}$ & $\begin{array}{l}6391 \\
(117)\end{array}$ & $\begin{array}{c}-67^{*} \\
( \pm 4)\end{array}$ & $\begin{array}{c}6575 \\
(91)\end{array}$ & $\begin{array}{l}28^{*} \\
( \pm 2)\end{array}$ \\
\hline Quintero/Santo Domingo & $\begin{array}{c}3955 \\
(35)\end{array}$ & $\begin{array}{c}11 \\
( \pm 3)\end{array}$ & $\begin{array}{c}3934 \\
(37)\end{array}$ & $\begin{array}{l}-65^{*} \\
( \pm 2)\end{array}$ & $\begin{array}{c}3966 \\
(34)\end{array}$ & $\begin{array}{l}39^{*} \\
( \pm 3)\end{array}$ \\
\hline Puerto Montt & $\begin{array}{c}2013 \\
(46)\end{array}$ & $\begin{array}{c}34 \\
( \pm 2)\end{array}$ & $\begin{array}{c}1930 \\
(20)\end{array}$ & $\begin{array}{c}-37^{*} \\
( \pm 5)\end{array}$ & $\begin{array}{c}2067 \\
(8)\end{array}$ & $\begin{array}{c}10 \\
( \pm 1)\end{array}$ \\
\hline Punta Arenas & $\begin{array}{c}988 \\
12\end{array}$ & $\begin{array}{c}-8 \\
( \pm 2)\end{array}$ & - & - & - & - \\
\hline
\end{tabular}

*Significant at $95 \%$.

\section{REFERENCES}

Aceituno, P. 1996. Elementos del clima en el altiplano sudamericano. Rev. Geofís., 44, 37-55.

Aceituno, P., H. Fuenzalida and B. Rosenblüth. 1993. Climate along the extratropical west coast of South America. In Mooney, H.A., E.R. Fuentes and B.I. Kronberg, eds. Earth system responses to global change: contrasts between North and South America. San Diego, CA, Academic Press, 61-69.

Adam, J.C., E.A. Clark, D.P. Lettenamier and E.F. Wood. 2006. Correction of global precipitation products for orographic effects. J. Climate, 19(1), 15-38.

Aniya, M. 1988. Glacier inventory for the Northern Patagonia Icefield, Chile, and variations 1944/45 to 1985/86. Arct. Alp. Res., 20(2), 179-187.

Boiser, J.P. and P. Aceituno. 2006. Changes in surface and upper-air temperature along the arid coast of northern Chile. In Proceedings of the Eighth International Conference on Southern Hemisphere Meteorology and Oceanography, 24-28 April 2006. Foz do Iguaçu, Brazil, Foz do Iguaçu, INPE. 227-228.

Bown, F. 2004. Cambios climáticos en la región de Los Lagos y respuestas recientes del glaciar Casa Pangue $\left(41^{\circ} 08^{\prime} \mathrm{S}\right)$. (MSc thesis, Universidad de Chile.)

Bown, F. and A. Rivera. 2007. Climate changes and recent glacier behaviour in the Chilean Lake District. Global Planet. Change. 59(1), 79-86.

Bradley, R.S., M. Vuille, H.F. Diaz and W. Vergara. 2006. Threats to water supply in the tropical Andes. Science, 312(5781), 1755-1756.

Carrasco, J., G. Casassa and A. Rivera. 2002. Meteorological and climatological aspects of the Southern Patagonia Icefield. In Casassa, G., F. Sepúlveda and R. Sinclair, eds. The Patagonian ice fields: a unique natural laboratory for environmental and climate change studies. New York, Kluwer Academic/Plenum Publishers, 29-41.

Carrasco, J.F., G. Casassa and J. Quintana. 2005. Changes of the $0^{\circ} \mathrm{C}$ isotherm and the equilibrium line altitude in central Chile during the last quarter of the 20th century. Hydrol. Sci. J., 50(6), 933-948.

Casassa, G. 1995. Glacier inventory in Chile: current status and recent glacier variations. Ann. Glaciol., 21, 317-322.

Casassa, G., A. Rivera and M. Schwikowski. 2006. Glacier massbalance data for South America $\left(30^{\circ} \mathrm{S}-56^{\circ} \mathrm{S}\right)$. In Knight, P.G., ed. Glacier science and environmental change. Oxford, etc., Blackwell, 239-241.

Casassa, G. and 6 others. 2008. Current status of Andean glaciers. Global Planet. Change, 59(1), 1-9.
Condom, T.H. 2002. Dynamiques d'extension lacustre et glaciare associées aux modifications du climat dans les Andes Centrales. (PhD thesis, Université Paris VI-Pierre et Marie Curie.)

Condom, T.H., A. Coudrain, J.E. Sicart and S. Théry. 2007. Computation of the space and time evolution of equilibriumline altitudes on Andean glaciers $\left(10^{\circ} \mathrm{N}-55^{\circ} \mathrm{S}\right)$. Global Planet. Change, 59(1), 189-202.

Escobar, F., G. Casassa and V. Pozo. 1995. Variaciones de un glaciar de Montaña en los Andes de Chile Central en las últimas dos décadas. Bull. Inst. Fr. Étud. Andin. [Lima], 24(3), 683-695.

Falvey, M. and R. Garreaud. 2005. Moisture variability over the South American Altiplano during the South American Low Level Jet Experiment (SALLJEX) observing season. J. Geophys. Res., 110(D22), D22105. (10.1029/2005JD006152.)

Falvey, M. and R. Garreaud. 2007. Winter precipitation episodes in central Chile: associated with meteorological conditions and orographic influences. J. Hydromet., 8, 171-193.

Fox, A.N. 1993. Snowline altitude and climate in the central Andes $\left(5-28^{\circ} \mathrm{S}\right)$ at present and during the Late Pleistocene glacial maximum. (PhD thesis, Cornell University.)

Giese, B.S., S.C. Urizar and N.S. Fuckar. 2002. Southern Hemisphere origins of the 1976 climate shift. Geophys. Res. Lett., 29(2), 1014. (10.1029/2001GL013268.)

Hastenrath, S.L. 1971. On the Pleistocene snow-line depression in the arid regions of the South American Andes. J. Glaciol., 10(59), 255-267.

Holmlund, P. and H. Fuenzalida. 1995. Anomalous glacier responses to 20th century climatic changes in Darwin Cordillera, southern Chile. J. Glaciol., 41(139), 465-473.

Ibarzabal, T., T. Donángelo, J.W. Hoffman and R. Naruse. 1996. Recent climate changes in southern Patagonia. Bull. Glacier Res. 14, 29-36.

Jóhannesson, T., C. Raymond and E. Waddington. 1989. Time-scale for adjustment of glaciers to changes in mass balance. J. Glaciol., 35(121), 355-369.

King, J.C. 1994. Recent climate variability in the vicinity of the Antarctic Peninsula. Int. J. Climatol., 14(4), 357-369.

Lemke, P. and 10 others. 2007. Observations: changes in snow, ice and frozen ground. In Solomon, S. and 7 others, eds. Climate change 2007: the physical science basis. Contribution of Working Group I to the Fourth Assessment Report of the Intergovernmental Panel on Climate Change. Cambridge, etc., Cambridge University Press, 337-383.

Marshall, G.J., P.A. Stott, J. Turner, W.M. Connolley, J.C. King and T.A. Lachlan-Cope. 2004. Causes of exceptional atmospheric circulation changes in the Southern Hemisphere. Geophys. Res. Lett., 31(14), L14205. (10.1029/2004GL019952.) 
Möller, M., C. Schneider and R. Kilian. 2007. Glacier change and climate forcing in recent decades at Gran Campo Nevado, southernmost Patagonia. Ann. Glaciol., 46, 136-144.

New, M., D. Lister, M. Hulme and I. Makin. 2000. A high-resolution data set of surface climate over global land areas. Climate Res. 21, 1-25.

Osorio, R. 2006. Estudio de la variabiliad reciente de la altura de la línea de nieves en la Cordillera de Los Andes $\left(18^{\circ}-55^{\circ} \mathrm{S}\right)$. (Undergraduate thesis, Universidad de Valparaíso.)

Porter, S.C. and A. Santana. 2003. Rapid 20th century retreat of Ventisquero Marinelli in the Cordillera Darwin Icefield. An. Inst. Patagonia, 31, 17-26.

Quintana, J. 2004. Estudio de los factores que explican la variabilidad de la precipitación en Chile en escalas de tiempo interdecadal. (MSc thesis, Universidad de Chile.)

Rasmussen, L.A., H. Conway and C.F. Raymond. 2007. Influence of upper air conditions on the Patagonia icefields. Global Planet. Change, 59(1), 203-216.

Rignot, E., A. Rivera and G. Casassa. 2003. Contribution of the Patagonian icefields of South America to sea level rise. Science, 302(5644), 434-437.

Rivera, A., G. Casassa, C. Acuña and H. Lange. 2000. Variaciones recientes de glaciares en Chile. Rev. Invest. Geogr., 34, 29-60.

Rivera, A., C. Anuña, G. Casassa and F. Bown. 2002. Use of remotely sensed and field data to estimate the contibution of Chilean glaciers to eustatic sea-level rise. Ann. Glaciol. 34, 367-372.

Rivera, A., F. Bown, G. Casassa, C. Acuña and J. Clavero. 2005. Glacier shrinkage and negative mass balance in the Chilean Lake District $\left(40^{\circ} \mathrm{S}\right)$. Hydrol. Sci. J., 50(6), 963-974.

Rivera, A., C. Acuña and G. Casassa. 2006. Glacier variations in central Chile $\left(32^{\circ} \mathrm{S}-41^{\circ} \mathrm{S}\right)$. In Knight, P.G., ed. Glacier science and environmental change. Oxford, etc., Blackwell, 246-247.

Rivera, A., T. Benham, G. Casassa, J. Bamber and J.A. Dowdeswell. 2007. Ice elevation and areal changes of glaciers from the
Northern Patagonia Icefield, Chile. Global Planet. Change, 59(1-4), 126-137.

Rosenblüth, B., G. Casassa and H. Fuenzalida. 1995. Recent climatic changes in western Patagonia. Bull. Glacier Res. 13, 127-132.

Rosenblüth, B., H.A. Fuenzalida and P. Aceituno. 1997. Recent temperature variations in southern South America. Int. J. Climatol., 17(1), 67-85.

Rosenzweig, C. and 9 others. 2007. Assessment of observed changes and responses in natural and managed systems. In Canziani, O.F., M.L. Parry and J.P. Palutikof, eds. Climate change 2007: climate change impacts, adaptation and vulnerability. Contribution of Working Group II to the Fourth Assessment Report of the Intergovernmental Panel on Climate Change. Cambridge, etc., Cambridge University Press, 79-131.

Schneider, C., M. Glaser, R. Kilian, A. Santana, N. Butorovic and G. Casassa. 2003. Regional climate variations across the southern Andes at 53 ${ }^{\circ}$ S. Phys. Geogr., 24(2), 97-119.

Solomon, S. and 7 others. 2007. Climate change 2007: the physical science basis. Contribution of Working Group I to the Fourth Assessment Report of the Intergovernmental Panel on Climate Change. Cambridge, etc., Cambridge University Press.

Strelin, J. and R. Iturraspe. 2007. Recent evolution and mass balance of Cordón Martial glaciers, Cordillera Fueguina Oriental. Global Planet. Change, 59(1), 17-26.

Trenberth, K.E. and 11 others. 2007. Observations: surface and atmospheric climate change. In Solomon, S. and 7 others, eds. Climate change 2007: the physical science basis. Contribution of Working Group I to the Fourth Assessment Report of the Intergovernmental Panel on Climate Change. Cambridge, etc., Cambridge University Press, 235-336.

Vuille, M. and R.S. Bradley. 2000. Mean annual temperature trends and their vertical structure in the tropical Andes. Geophys. Res. Lett., 27(23), 3885-3888.

Zhang, Y., J.M. Wallace and D.S. Battisti. 1997. ENSO-like interdecadal variability. J. Climate, 10(5), 1004-1020. 